\title{
Making Investment Decisions in a Chilean Family-Oriented Business: Who is Right the Parents or the Children?
}

\author{
Orlando Llanos \\ Universidad Católica de la Santísima Concepción \\ E-mail: ollanos@ucsc.cl \\ Fredy Valenzuela \\ University of New England and Universidad de Talca \\ E-mail: fvalenzu@une.edu.au
}

\begin{abstract}
The relevance of traditional methods of project evaluation in the decision-making process for family-oriented businesses is not completely clear, as compared with the importance of other variables such as the project's coherence with the family's values and interests, amongst others. This article presents a case study related to a Chilean family business, in its attempt to determine the importance that family members attribute to different variables that should be considered when making investment decisions. The investigation considered three types of data: a) evaluation of the investment from a financial and strategic point of view, b) presentation of results to the member of family, and c) follow-up with respect to the decision made and interviews with all the family members. The results show that the parents feel that stability in the family investment policies and the impact of the investment on the roles that each family member plays in the business are the most relevant variables, whereas the children assign more value to aspects associated with business returns.
\end{abstract}

Keywords: Investment Decision, Family Business, Small Business

\section{INTRODUCTION}

The study of investment decisions has gained importance recently, due to the recognition of their irreversible nature, which implies a high degree of commitment (Ghemawat \& Del Sol, 1998). Thus, distinct techniques and methods have been developed to support and facilitate this type of decision (Del Sol \& Ghemawat, 1999). 
Financial theory indicates that a company should carry out all investment projects that offer a Net Present Value (NPV) greater than zero or an internal rate of return (IRR) greater than the capital cost, as this will benefit the shareholders or company owners (Ross, Westerfield \& Jaffe, 1997). These rules are widespread in finance texts and in our classrooms, along with others that are framed within the methodology of discounted cash flows (Brealey \& Myers, 1991). Nonetheless, Del Sol \& Ghemawat (1999) state that these methods do not explicitly consider competition and that they show other important limitations such as: (1) poor practices in their application, for example, a poor treatment of inflation, excessive adjustments of risk, inadequate criteria of returns, or the separation of complementary projects, amongst others (Hodder \& Riggs, 1985); (2) the inability to quantify intangible assets or organizational capacities; and (3) the lack of evaluation of flexibility under uncertainty or not considering the value of the options. Moreover, the evaluation of the investment decision is normally seen as the creation of new businesses, although most studies are done for businesses that are already operating (Sapag, 2001).

According to Kaplan \& Ruback (1995), some studies confirm the benefits of discounted cash flow techniques, which provide reliable estimates of the market value of an investment. In this sense, the study by McConnell \& Muscarella (1985) found increased market values for most industrial companies when these announced planned investments. Likewise, Woolridge (1988) reported that stock values have a strong positive reaction to announcements such as increased investment in research and development, new product strategies, and investments in expansion and modernization.

Del Sol (1999) also indicated that projects with a long-term NPV $>0$ are the exception, as already pointed out by Leftwich \& Eckert (1987), who found that extraordinary utilities do not exist in the long term. Given this, the criteria of discounted cash flow techniques should be considered to be important tools that allow the evaluation of investment decisions, but that simple calculations in a discounted cash flow analysis can, at times, lead to the erroneous calculation of a positive NPV (Ross, Westerfield \& Jaffe, 1997) and, therefore, the origin of such numbers should be investigated (Brealey \& Myers, 1996).

It is agreed that managers have two general criteria available for evaluating strategic investment decisions in highly uncertain and competitive markets - cash flow techniques and competitive strategy schemes - and that, in practice, these methods are not integrated (Del Sol, 1999), but could and should be (Hax \& Majluf, 1996; Porter, 1980, 1985). Given the generally irreversible nature of strategic investments, it is necessary to predict the uncertain future in many aspects such as the behavior of 
competitors and suppliers, technological changes, and oscillations in supply and demand (Del Sol \& Ghemawat, 1999). It is also necessary to understand how the company's position; cost of opportunity; levels of operational, financial, and competitive risk; and the competitive position adopted by other players in the same industry impact the configuration of the company's value chain, as well as their effect on the company's development of a competitive advantage (Llanos, 2005). Thus, it is necessary to consider the structure of the industry in which the business will be acting, making this compatible with the resources and capacities that the company has for carrying out the project (Andalaft \& Quezada, 2001). Given that the company seeks to obtain better-than-normal economic returns, it is necessary to create and maintain a competitive advantage (Porter, 1996); this is developed by the business in the framework of the competitive structure of the industry in which it competes (Porter, 1980).

The academic literature proposes diverse bases that can generate a competitive advantage as a source of better than normal income, including the organizational resources and capacities of the project, whether taken from other businesses in a portfolio or developed by the project itself (Collins \& Montgomery, 1995). Wernerfelt (1984) indicated that resources and capacities can be the basis for an income explained by a NPV $>0$, stating that the unique resources and capacities of a company cannot be bought and sold freely on the market, providing the means for sustaining the competitive advantage. In turn, Barney (1991), Wernerfelt (1984), Dierickx \& Cool (1989), and Peteraf (1993) state that, for the resources to be a source of a sustainable competitive advantage, they must meet fundamental conditions such as: being valuable, unique, imperfectly imitable, and not substitutable by other strategically equivalent resources. Another line of thought that seeks to explain the source of the competitive advantage and to understand the reason why a NPV $>0$ is the vision of a company based on its activities, Porter (1985) introduced a model based on activities that indicates that a business obtains its advantage by performing activities strategically cheaper or better than its competitors; in the paper "Towards a Dynamic Theory of Strategy" (1991), Porter continued to perfect this approach, including the resources within the general analysis framework, citing that: "if the managers could understand their competitive environment, they could creatively identify favorable positions that are different from their competitors, unite the required abilities and assets, configure the appropriate value chain, and implement organizational arrangements and a culture that reinforces the required behavior". 
With regards to family businesses, attempts to relate this topic to the management of family businesses have been made by diverse academics, albeit not directly dealing with the matter analyzed herein. The first such work set out to clarify what is understood by "family business"; a consensus regarding this definition remains elusive in the literature (Chrisman, Chua \& Sharma, 2005). Miller and Rice (1967) indicated that the involvement of family in a company distinguishes it as a family business, whereas most researchers interpret family involvement as ownership and administration (Handler, 1989). Churchill \& Hatten (1997) added the requirement of a successor. After analyzing numerous definitions, Chua, Chrisman, and Sharma (1999) concluded that, in spite of the differences that persist in the academy and the lack of a clear definition by the owners of such companies as to what constitutes a family business, a certain level of agreement seems to exist such that ownership and administration of the business by a family makes it a family business. In this regard, Danielson \& Scott (2007) refer to the influence of the concentration of property and control on the decision of investing. They explain that the conflicts of agency could influence the decision of investment of the small businesses where there is a strong link between property and control. In addition, they mentioned that two types of situations may happen: under investment and over investment. Under investment happens more often in businesses that are growing, have their property and control systems more concentrated. On the other hand, over investment happens more often to businesses that have property and control systems less concentrated.

Specifically, in matters of investment decisions, Ward (2001) indicated that businesses controlled by families maintain a higher degree of stability in this type of decision during recession periods as compared with the companies on the stock market and, moreover, this author states that the former type of company maximizes better their cash flow, whereas their public counterparts prefer to sacrifice cash in favor of operational utilities for matters of accounting. . These differences occur because the family involvement in the company infiltrates the strategic decisions of the business (Ward, 2002); in family businesses, the roles of the family and business are superimposed and not easily made compatible (Dodero, 2002); this sets the family business apart, so that the management of this type of company cannot be studied as traditional businesses (Chua, Chrisman, \& Sharma, 1999).

In keeping with the above paragraph, Chrisman, Chua, and Sharma (2005) presented empirical evidence that family involvement affects the capacity of the firm to create value, whereas Ward (2001) indicated that the family contributes values and goals, removing independence from strategic decision-making, for instance, in the case 
of investment decisions. Ward (2001) adds that the structure, character, and history of the family owner define several aspects of the strategy, amongst others, the priorities in the assignation of resources, which is reaffirmed by Dodero (2002), who adds that avoiding intervention by elements such as family philosophy, values, and goals in business decisions should also be studied, so that they do not become obstacles that hinder the endurance of these companies over successive generations. Dodero (2002) also indicates that the family values are what form the family's vision of their business, thereby explaining or rationalizing the behavior and management decisions that they make.

Although the information presented above indicates that family ties tend to oppose business (Dodero, 2002), for Ward (2002) companies controlled by families are guided by more solid investment motives, since when the owners are the managers (or are closely tied to them), it is not very likely that the management will seek to satisfy its own interests if these are contrary to those of the owners. The costs or benefits of family involvement in the business and the family's degree of influence over these decisions is a constant in this area, as reaffirmed by the study carried out by Degadt (2003), who indicated that the interaction between family businesses and the involvement of the family in the company can have positive or negative effects. In this sense, whereas in the traditional literature with respect to the theory of agency, it is assumed that when the ownership and administration occur within a family, the costs of agency should be low or null (Chrisman, Chua \& Sharma, 2005), the literature related to the family economy indicates that the tendency towards altruism can cause problems of self-control and generate costs of agency in this type of company (Schulze et al., 2001; Schulze, Lubatkin \& Dino, 2003). The same is true for entrenchment, as Gómez-Mejia, Núñez-Nickel \& Gutierrez (2001) showed through empirical evidence. It should be noted that entrenchment can also occur with ownership, which can have serious consequences for the family groups that have minority participation in the ownership (Chrisman, Chua \& Sharma, 2005).

Ward (2002) and Davis (2006) indicated that normally family businesses tend to be perceived as undisciplined and unprofessional by investors, who consider the family culture of loyalty, paternalism, and nepotism to affect the managerial capacity and decision-making in matters of investment and, although many times this is not justified (Davis, 2006), it has a negative impact on access to foreign capital, which is certainly a disadvantage at the moment of making investments (Ward, 2002). The participation of the family in the business makes these companies unique (Chua, Chrisman \& Sharma, 1999) and the objectives and desires of the family group may be 
more relevant in the decision-making process of this type of company (Degadt, 2003). Moreover, the economic setting in many countries (including Chile) is dominated by family businesses (Astrachan \& Shanker, 2003; Morck \& Yeung, 2004) and, therefore, the academy should begin to recognize the relevance of these companies (Chrisman, Chua \& Sharma, 2005).

Thus, this article seeks to understand the variables that are taken into account by family businesses when making investment decisions. The present work attempts to answer questions such as how much traditional discounted cash flow techniques models influence the investment decisions that a family makes for its company; the importance of the project's strategic impact on the company; how influential the family interests are in this type of decision; and whether all family members involved in management prioritize economic and family variables to the same degree. Thereby offering a unified approach to the problem of family influence on the strategic management of the company in investment decisions.

\section{RESEARCH METHODOLOGY}

The study consisted of qualitative research, seeking to apply part of the instrument proposed by Rialp i Criado (1998), who indicated four basic design types for case studies. One of these is the study of a single case or unit of analysis, which is applied herein. The present work studied the case of a small family business from Nuble Province, Region VIII, Chile. Two criteria were applied when selecting this company for the study:

1. The company had to be interested in evaluating an investment project of high strategic commitment, and

2. The company had to be willing to provide the information necessary to evaluate the project in order to carry out this research.

Once the business under study was selected, information was collected following the recommendations of Rialp i Criado (1998), who indicated that the study proposed should consider different and converging sources of evidence, applying the concept of triangulation, giving robust consideration to the fact.

Given this, the following three steps were taken. First, the investment was evaluated from a financial and strategic point of view, using the method of discounted cash flow techniques, sensitized through the Montecarlo method and strategic analyses of industrial attractiveness, strategic analysis by firm activities and resources, and an analysis of the corporative impact of the project. Second, a presentation of the 
economic results was delivered to the family members; and finally, a follow-up with respect to the decision made and interviews with all the family members directly involved in the management of the business, including both parents and the one child presently tied to the management and decisions of the company. These interviews consisted in a self-administered questionnaire that contained a series of variables extracted from the bibliographic review were considered. These variables were divided into two major dimensions: a) financial-strategic variables, and b) variables associated with the family business (see Table 1).

Table 1 Variables that could influence the investment decision in the business under study

\section{FINANCIAL - STRATEGIC VARIABLES}

1. Economic result of the project evaluation

2. Attractiveness of the industry in which the project will compete

3. Synergic potential with current business dealings

4. Complexity of the activities of the new business

5. Position of advantage with respect to tangible assets

6. Position of advantage with respect to intangible assets and capacities of the firm

\begin{tabular}{l}
\hline VARIABLES ASSOCIATED WITH THE FAMILY BUSINESS \\
\hline 7. Impact on the stability of the company's current investment policies \\
8. Impact of the project on the roles played by each family member \\
9. Coherence of the project with the family's values and interests \\
10. Coherence of the project with the structure, character, and history of the company \\
11. Interest in benefiting some member of the family with the project \\
12. Concentration of power in decision-making \\
13. Access to financing through the market
\end{tabular}

The objective of the already mentioned interviews was to determine the reasons behind the final decision. In order to determine the level of importance of these variables, the members of the family were asked to allocate 100 points among the 13 variables. With regards to the evaluation of these variables, a scale that went from 1 to 7 was used; in where 7 was the highest and 1 the lowest evaluation. To check the reliability of these scales their internal reliability and item analysis was checked as suggested by Churchill (1979). A cutoff point of 0.70 was considered for the retention of factors as recommended by Nunnally (1978) and Peterson (1995). In addition, a cutoff point of 0.4 was considered for the corrected item-to-total correlations as recommended by Boshoff (1999). 


\section{DISCUSSION AND RESULTS}

The first decision to be made in investigation was the selection of the business under study. Considering the criteria established in the methodology section, Comercial y Agrícola ML was chosen.

Comercial y Agrícola ML is a small company in Nuble Province, Region VIII (also known as the Bío Bio Region), with over 40 years of trajectory. It has developed under the care of a family made up of the father (Manuel), the mother (Eugenia), and their four children. The owners have always been tied to the country and do not have any professional studies, whereas their four children have university or technical degrees. The family business is presently facing increased sales, which generates certain cash availability; the incorporation of a professional child (Civil Agricultural Engineer) into the company activities; strong fluctuations in prices; and problems for selling their traditional grape harvest, which is the most important product in terms of agricultural sales. Comercial y Agrícola ML currently has investments in two business areas: (1) commerce and (2) agricultural-forestry exploitation. The commercial area consists of a mini-market located in a rural township of Ñuble Province, offering approximately 6000 products, with nine full-time employees and another three to five part-time employees according to the time of year. The mini-market includes a bakery, butcher shop, groceries, hardware, and agricultural supplies. It also includes a fuel (gas) distribution service and is also a distributor of alcoholic beverages (practice, operating as an additional service of the supermarket). In the area of agricultural-forestry exploitation, the family maintains investments mainly in livestock, traditional agricultural farming, and small forestry plantations, all on 500 hectares of land, of which approximately 350 are leased (the lease expires in 2009 and is renewable to 2013), and 150 are owned by the company. On these lands, the business administers approximately 55 hectares of vineyards of Chilean and Italian grape varieties, which are nearly all sold at market prices. It should be noted that, approximately 15 years ago, Comercial y Agrícola ML acquired a winery with a current approximate production capacity of 35.000 liters; the potential capacity of wine-production with the company's current vineyard varies between 350.000 and 400.000 liters per year. The agricultural and forestry area employs three people full-time, adding up to as many as 30 seasonal workers for the pruning and harvest seasons. The sales of the company in 2004 were US\$528,302 and sales in 2005 were estimated to exceed US\$566.038. Moreover, a record was made of the company's activities and the commercial value was appraised to be around US\$594.340 in October 2005. 


\section{Description of the Investment Project}

The investment project consisted in determining whether or not to enter the wholesale wine production and sale business for the local market, which would allow the business to resolve a current weakness related to their production of grapes for wine, which is controlled by the market of industrial clients and includes difficulties in product sales. This project would require moving from a non professional stage to a more professional one of management and also implied that the father would delegate greater autonomy to the professional child. The project contemplated the construction and management of a winery of mainly traditional or wholesale wines; the estimated investment was US\$673,585. The investment project contemplated a production volume of 800,000 liters: 500 liters red wine (wholesale), 200,000 liters white wine (wholesale), 70,000 liters bottled Cabernet Sauvignon, and 30,000 liters Sauvignon Blanc (packaged for retail).

The following presents the main findings of the research, classified in function of the three stages of the research process described in the methodology.

\section{Evaluation of the Investment from a Financial-Strategic Point of View}

From a technical point of view, an economic evaluation of the project was carried out along with competitive and strategic analyses. This involved the analysis of the six financial-strategic dimensions presented in Table 1.

Financial Results of the Project Analysis. The economic-financial analysis showed a project with a Net Present Value (NPV) equal to UF2 35,500 (US $\$ 1,180,000 ; \mathrm{UF}=$ Unidad de Fometo, an incremental monetary unit used in Chile to adjust for the effects of inflation) for the project alone, UF 36,200 (US \$1,200,000) for the financed project, and an internal rate of return (IRR) of 29 percent. The sensitization of the cash flows presented a NPV $>0$ in most of the scenarios analyzed. The project flows allowed adequate coverage of the debt, the assets and flows of the company generated access to financing at a reasonable cost, and the company's debt structure, even were it to be strongly increased, would be maintained at controllable levels for the firm (around 40 percent of the total value of the assets). Additionally, the growth rate of the sales, the price of the products, and the cost of the raw materials were sensitized jointly and separately using the Montecarlo analysis. Table 2 and Figure 1 show the results of the joint sensitization of the variables mentioned. These show that only 12 percent of the 10,000 simulated scenes resulted in a negative NPV, confirming the financial convenience of the project. 
Table 2 Result of Joint Sensitization, Montecarlo analysis

\begin{tabular}{|c|c|}
\hline Number of Variables & 16 \\
\hline Number of replicates & 10000 \\
\hline Average & UF27421.30 \\
\hline Standard deviation & UF 23304.26 \\
\hline Minimum value & UF -53177.40 \\
\hline Maximum value & UF 121882.66 \\
\hline Percent negative & 12 \\
\hline
\end{tabular}

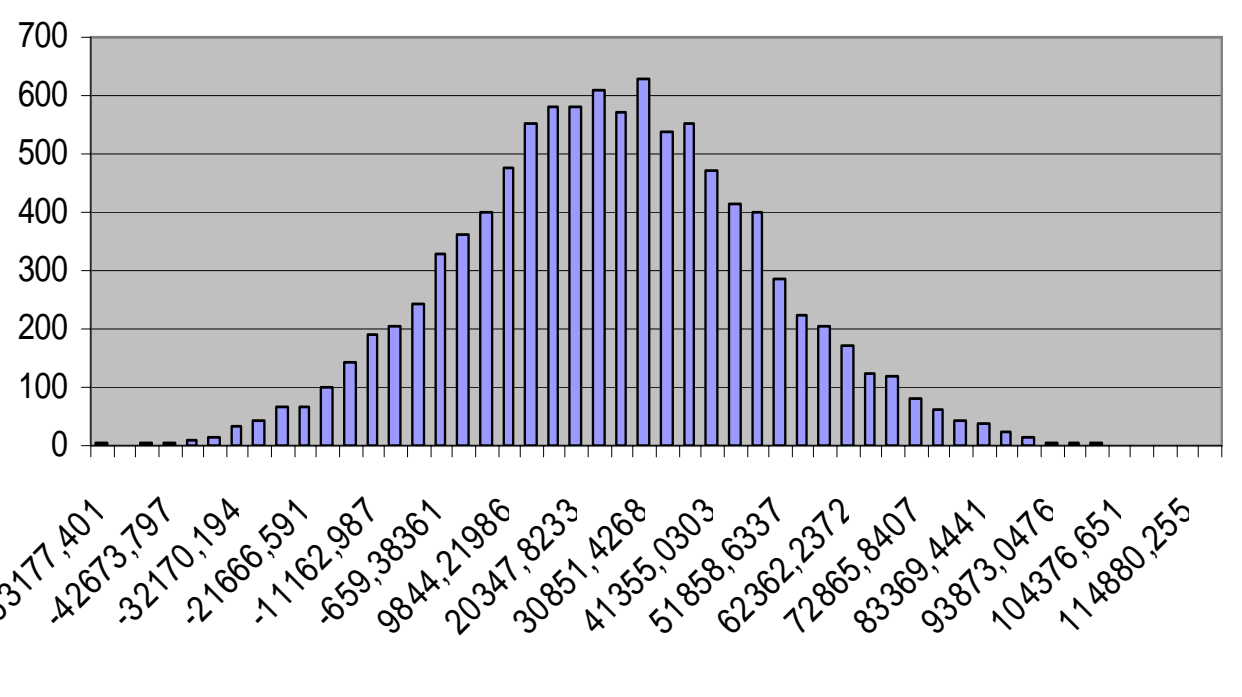

Figure 1 Histogram of The NPV Distribution Of The Project (10,000 Scenarios)

Analysis of Attractiveness of the Businesses Being Considered. The sector in question was shown to be fairly attractive, as explained principally by the high fragmentation of the industry, especially in the strategic group in which the company intended to compete. This offered the possibility for competitive development in unattended niches. Furthermore, the market segment selected for the project was eminently artisanal and non-competitive, which is considered to be an opportunity. The attraction of the sector decreased mainly due to the high market power of the buyers and distributors. 
Synergic Potential with the Present Dealings of the Business. The position of the company was considered to be favorable; that is, the synergic potential was high, and the reasons for this are as follows:

1. Integration with respect to the agricultural business of grape production assured access to low-cost raw materials, decreasing uncertainty in both businesses.

2. Although on a smaller scale, the family had prior knowledge of the wine industry, especially in the segments of wholesale and artisanal wine markets.

3. The company has access to a market for at least 15 to 20 percent of the maximum production capacity of the project.

Complexity of the Activities of the New Business. With this project, the family would face the challenge of developing a more complex business than those being managed to date. This new project requires a certain level of professionalism in the management, to be provided by the professional child, who is being incorporated into the company's activities. Special attention is required for the commercial function, which is considered to be critical to the success of the project. This dimension of analysis is perhaps the area in which the family business being analyzed shows its greatest vulnerability.

Position of Advantage With Respect to Tangible Assets. In this case, the position of the company is very favorable, since:

1. The family has access to land at a low cost of opportunity, with many fields being under-utilized; this condition would be maintained if some business is not developed that allows their rotation, since these lands will not be sold in the short term.

2. The company has access to good quality, low-cost raw materials for the project. The raw materials have a low market value, are an abundant resource in the area where the project will be developed, and the very family administers more than 50 hectares of vineyards that assure the supply of at least 60 percent of the resource required by the project.

Position of Advantage With Respect To Intangible Assets and Organizational Capacities. In this case, the situation of the company is less favorable. The project that is being considered for implementation is large-scale by company standards and incorporates new technology with which the family has no experience. Moreover, the company has no contracts signed for machinery or sales, they do not have an established distribution network for selling the production volume that they would be 
capable of producing, nor do they have a strong brand image outside of the immediate geographic market.

On the other hand, the company's financial state is healthy and has the capacity for generating stable flows, giving it access to reasonable-cost credit, which could cover the financial costs of the new project without great problems and provide a certain degree of tranquility in the implementation of the strategy for the new project. At a township level, the company is recognized for the quality of its homemade wines, giving it access to a market that could absorb between 15 and 20 percent of the production of the project within a normal scenario.

\section{Presentation of the Results to the Family Members}

After carrying out all the analyses previously indicated, two reports and two presentations were prepared with different levels of technical complexity to be presented to the parents and child involved in the business management. The reports were delivered in advance so that they could be reviewed by the interested parties and then the results were presented and the questions and concerns of the company owners were studied. Later, an interview was conducted with each member of the family in order to observe how they received the results of the work, determine what their final decision was, and learn on what parameters they based their final decision.

\section{Final Decision and Follow-Up}

In spite of the good financial results and the project's potential for creating value, the final decision of the family was not to move forward with the idea. In order to obtain information as to why that decision was made, each member of the family was asked to complete a questionnaire. With regards to the reliability of the dimensions considered in the study (e.g. financial-strategic variables and variables associated with the family business), both dimensions showed high internal consistency (e.g 0.80 and 0.85 respectively).

The results of the survey can be seen in Tables 3 and 4 and Figures 2 and 3. The main findings are discussed next.

Importance that the Family Members Attributed to the Variables under Study. Certain differences can be seen in the valuation of the different variables under study by the parents and the child. Clearly, the child attributed greater importance to the financial-strategic type variables (economic results of the project evaluation, position of sales in tangible assets, synergic potential of the new business); the child also attributed great importance to access to financing. On the other hand, the parents gave 
little importance to the financial-strategic variables, valuing much more the noneconomic elements (impact on the stability of the investment policies, impact on the roles that each person plays in the company). All this is coherent with the results obtained from the in-depth interviews, from which we can highlight statements such as:

1. The parents stated that "the project requires going into debt; we've never gone into debt."

2. The father also indicated: "This business is very complex for our family; we don't know if we can sell that amount and I'm not up for going here and there looking for new clients".

3. The mother spoke of her fear that "the involvement of the child in the project will cause conflicts between father and child".

4. The father also felt that the child was not prepared to assume responsibilities in the company.

5. Although the parents acknowledged that the project was a good alternative for integrating the child into the company, at the same time, they stated that this was not a matter of great importance to them.

6. The child, in turn, was optimistic about the results of the study, although recognizing the complexity of the project; the child also commented that this would remove the company from its structural axis, character, and history and that it would have a strong impact on the traditional investment policies of the company.

Family Evaluation of the Project According To the Studied Investment Variables. The 13 variables studied were evaluated by both the parents and the child. Table 4 and Figure 3 show that the best evaluated dimensions by the parents were the economic results, the position of advantage that the tangible assets of the company provided the project, and the altruistic interests of benefiting a specific member of the family. On the other hand, the worst-evaluated variables for the parents were the project coherence with the family values and interests, the impact of the project on the roles of each member within the company, and the impact on the stability of the company's investment policies. All this is coherent with the results of the in-depth interview carried out by the parents, in which they stated that one of their main motives for their evaluation of this project was "that the incorporation of the child into the management could develop new businesses that strengthen the company in the future". The parents also recognized the synergic potential of the business and the advantage of having lands at a low cost of opportunity, indicating that "the project could be a solution to the problems the family is facing in the sales of the grape production each year". 
Table 3 Level of Importance That the Different Family Members Attribute To the Financial-Strategic Variables and the Family Management Variables for Deciding About Implementing the Project

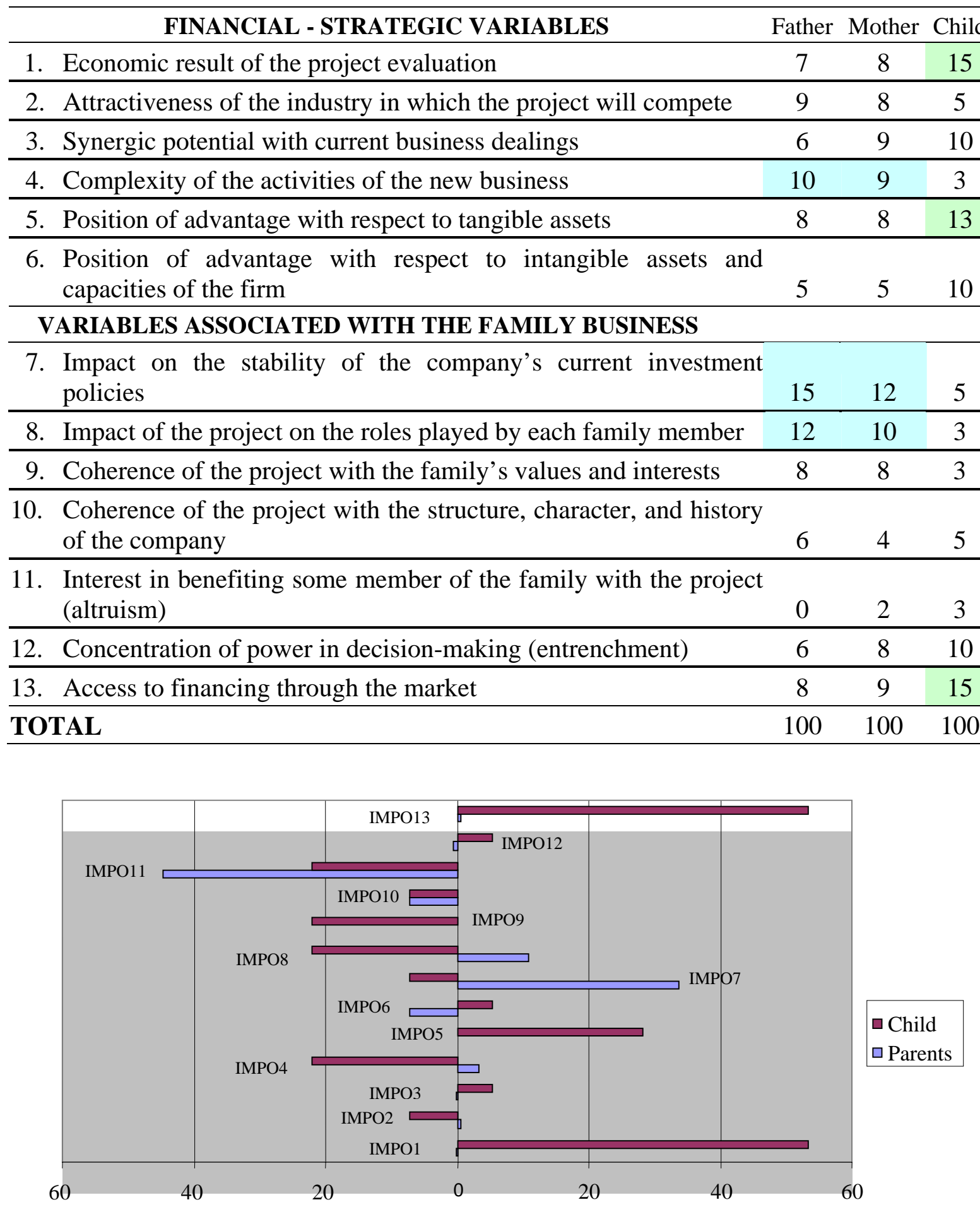

Figure 2 Level of Importance That The Different Family Members Attributed To The Financial-Strategic Variables And The Family Management Variables For Deciding About Implementing The Project 
As for the evaluation of the child, for each one of the variables studied, the best evaluated were the access to financing, the position of advantage with respect to the tangible and intangible assets, and the synergic potential of the new business, whereas the worst evaluated variables were the concentration of power in decision-making, the coherence of the project with the structure, character, and history of the company, the coherence of the project with the family interests, and the impact that it would have on the stability of the company's investment policies.

Table 4 Family Evaluation of the Project According To The Investment Variables Studied

\begin{tabular}{|c|c|c|c|}
\hline FINANCIAL - STRATEGIC VARIABLES & Ev. Father* & Ev. Mother* & Ev. Child* \\
\hline 1. Economic result of the project evaluation & 6 & 6 & 5 \\
\hline $\begin{array}{l}\text { 2. Attractiveness of the industry in which the } \\
\text { project will compete }\end{array}$ & 4 & 6 & 5 \\
\hline $\begin{array}{l}\text { 3. Synergic potential with current business } \\
\text { dealings }\end{array}$ & 6 & 5 & 6 \\
\hline $\begin{array}{l}\text { 4. Complexity of the activities of the new } \\
\text { business }\end{array}$ & 3 & 5 & 6 \\
\hline $\begin{array}{l}\text { 5. Position of advantage with respect to tangible } \\
\text { assets }\end{array}$ & 6 & 6 & 6 \\
\hline $\begin{array}{l}\text { 6. Position of advantage with respect to } \\
\text { intangible assets and capacities of the firm }\end{array}$ & 3 & 5 & 6 \\
\hline $\begin{array}{l}\text { VARIABLES ASSOCIATED WITH THE } \\
\text { FAMILY BUSINESS } \\
\end{array}$ & & & \\
\hline $\begin{array}{l}\text { 7. Impact on the stability of the company's } \\
\text { current investment policies }\end{array}$ & 3 & 3 & 4 \\
\hline $\begin{array}{l}\text { 8. Impact of the project on the roles played by } \\
\text { each family member }\end{array}$ & 3 & 3 & 3 \\
\hline $\begin{array}{l}\text { 9. Coherence of the project with the family's } \\
\text { values and interests }\end{array}$ & 2 & 3 & 3 \\
\hline $\begin{array}{l}\text { 10. Coherence of the project with the structure, } \\
\text { character, and history of the company }\end{array}$ & 2 & 5 & 3 \\
\hline $\begin{array}{l}\text { 11. Interest in benefiting some member of the } \\
\text { family with the project (altruism) }\end{array}$ & 6 & 6 & 5 \\
\hline $\begin{array}{l}\text { 12. Concentration of power in decision-making } \\
\text { (entrenchment) }\end{array}$ & 6 & 5 & 2 \\
\hline 13. Access to financing through the market & 5 & 5 & 6 \\
\hline
\end{tabular}

* The scale went from 1 (Poor/Pessimistic) to 7 (Excellent/Optimistic) 


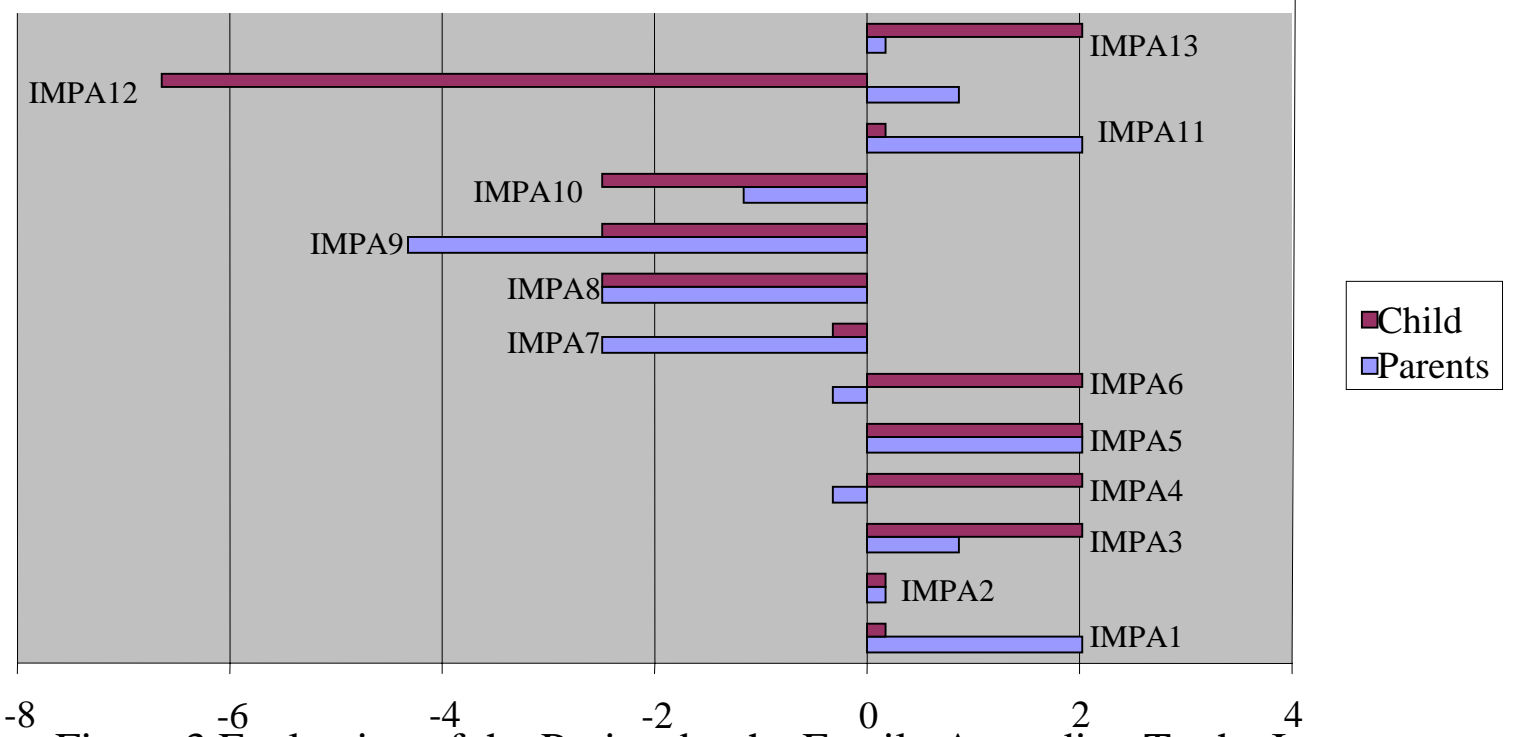

${ }^{-8}$ Figure $3 \stackrel{-6}{\text { Evaluation of }} \stackrel{-4}{4}{ }^{-2}{ }^{-2}$ Project by the Family According To the Investment Variables Studied

Bases for the Final Decision. As previously indicated, the final decision of the family was to not carry out the investment project. This decision was strongly influenced by the opinion of the parents with respect to the benefits of the project, in the context of the interests of the family and the manner in which they expected to project the business.

Figures 4 and 5 show the results of the interview in terms of the evaluation of the project based on the variables under study versus the importance that the parents and child gave these same variables.

The first thing that can be seen in these two figures is the high degree of agreement between the responses of the parents and the child in relation to their evaluation of the project based on each of the 13 variables studied; specifically, they coincide in six of the seven and eight variables evaluated as above average.

In relation to the importance they grant each of the 13 variables for deciding on the fate of the project, the scenario is radically different from the previous one. The degree of agreement between the average opinion of the parents and the child is very low, as they only coincide in two of the six and seven variables evaluated as above average.

The differences in the importance granted each of the variables under study by the parents and child show distinct criteria of decision-making in both cases. The relationship of importance versus evaluation changed the location of the variables in 
the graphs, revealing that the high valuation and good evaluation of the child for the variables associated with the creation of economic value were of little importance in the final decision given the poor evaluation and high impact the parents gave the noneconomic variables, such as the impact on the investment policy of the company, the impact of the project on the roles that each one plays in the business, and the coherence of the project with the family interests and values. All this shows the greater influence of the patriarchs of this family in the strategic decisions of the company, in spite of the wide difference in favor of the child in terms of professional formation. This is a consequence, as observed in the in-depth interviews, of the fact that the role of each interviewee within the family is replicated within the company. Consequently, in the case of this family business, the creation of economic value is not the most relevant element at the moment of strategically deciding the maximization of the value for the main owners of this company (the parents); rather, they are influenced by family-type variables such as those already indicated and the economic value of the business is a secondary element, at least in this case.

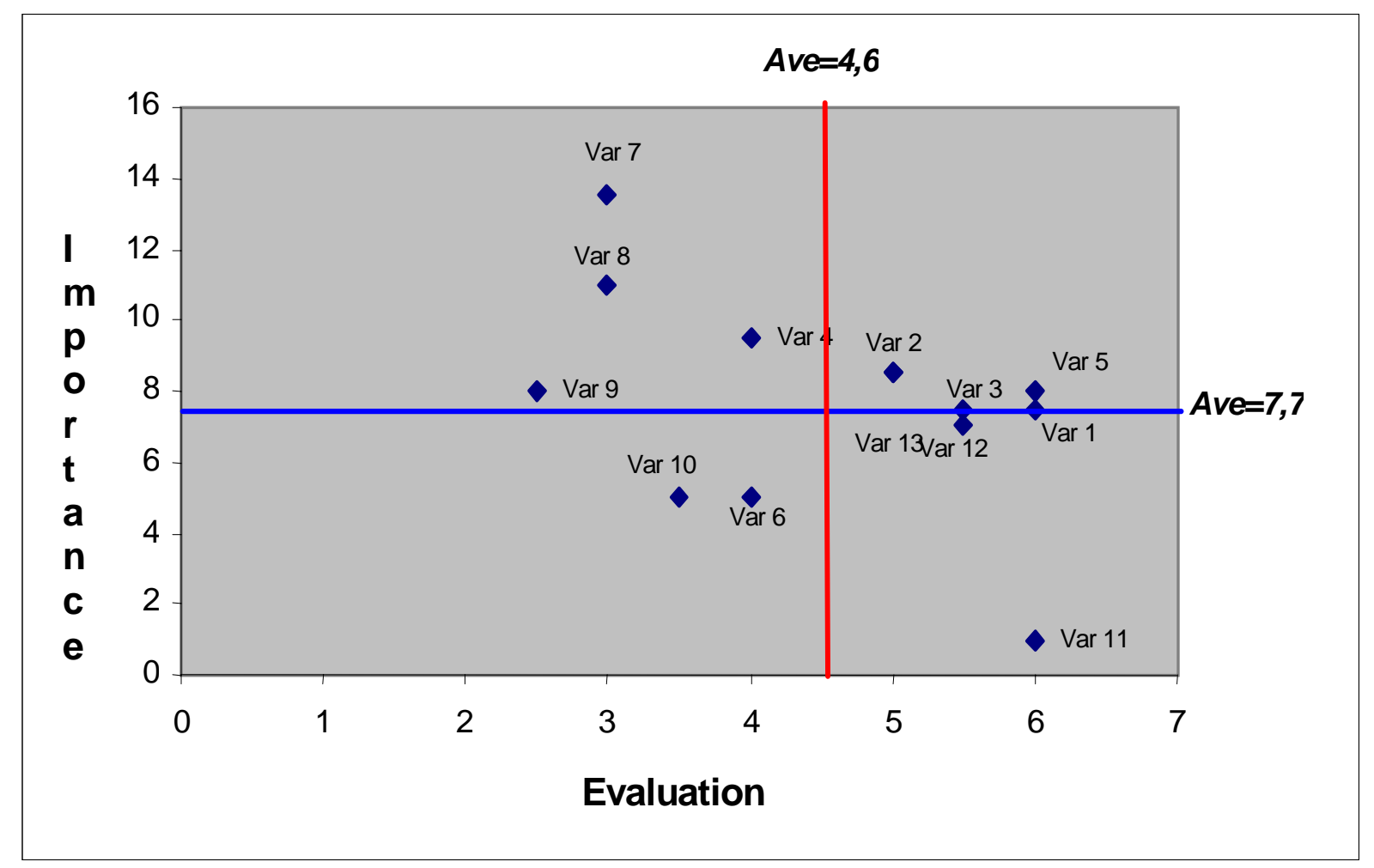

Figure 4 Average Evaluation v/s Average Importance 


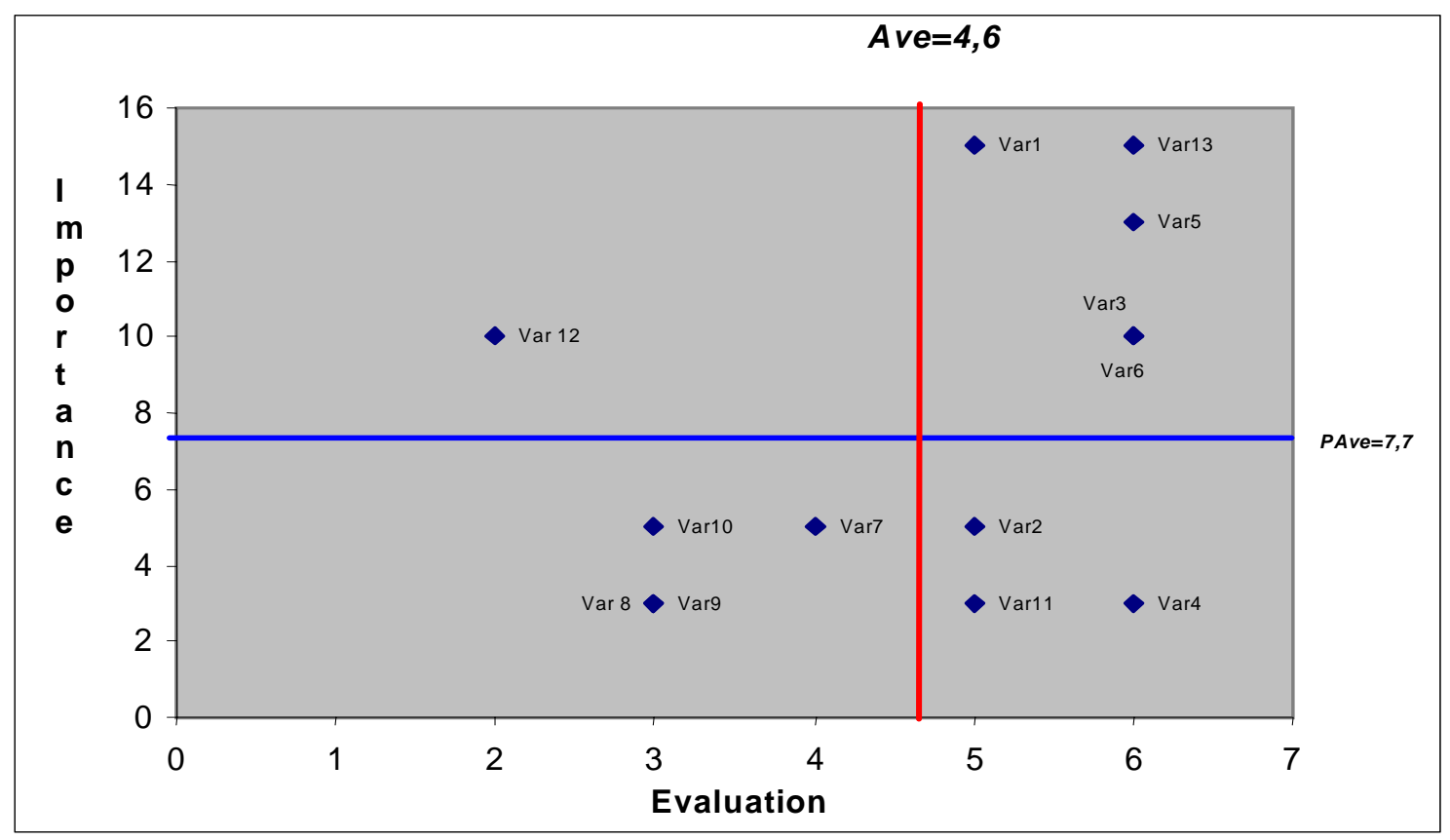

Figure 5 Evaluation v/s Importance for the Parents

\section{CONCLUSIONS}

The investigation seeked to understand the variables that are taken into account by family businesses when making investment decisions. Diverse findings and conclusions were inferred from this research.

1. In the first place, it can be shown that, for the case of the parents-administrators of the family company under study, the information provided by traditional methods of the project valuation, such as discounted cash flow techniques and sensitization, were not of primary relevance at the moment of making a decision about the fate of the investment project at hand. This is compared with the high importance given variables such as stability of the investment policy, the impact of the project on the roles that each of the family members plays in the company and the coherence of the project with the company structure, character, and history.

2. On the other hand, the order of importance granted the same variables by the child is different from that of the parents; in this case, the variables associated with the traditional methods and the elements of strategic coherence of the project were more relevant.

3. Parents and child showed a high degree of agreement in the evaluation of the project considering the 13 variables studied.

4. Despite the high degree of agreement in the evaluation of the 13 variables mentioned in the project, the criteria of the parents' and child's decisions varied as 
a consequence of the differences in the valuation of importance that each gave said criteria.

5. Whereas the child gave more importance to the variables associated with the business, the parents valued the impact of the project on the family much more.

With regards to managerial implications, this work allows us to obtain some practical recommendations for professionals in business management that are connected to the administration of this type of organization. The first is that they should keep in mind who makes or influences the strategic decisions of a company that is influenced by a family will differ from traditional companies. The family interests, values, and structures could strongly influence the strategic decisions in this type of organization. In the context of that indicated above, management professionals should consider that the traditional models used to support decisions such as investment lose importance and many times are not entirely applicable.

\section{LIMITATIONS AND FUTURE RESEARCH}

1. Because this deals with a single case study, the conclusions that are presented here are only valid for the company under study. Nevertheless, the study provides an approach to a little-studied topic.

2. The variables selected were extracted from a literature review, specifically to be applied in this case. These variables should be validated for new studies.

3. Given the limitations of this work, new studies on other family businesses, of different sizes and in other regions of the country and/or abroad are necessary.

4. It is also possible to advance in this work by placing these variables in an instrument that could be applied to a representative sample of family businesses, transforming the qualitative study into a quantitative one and, thus, giving greater validity to the results.

5. Finally, it is considered necessary to continue to research with respect to possible new variables or dimensions of influence in the strategic decisions of the family businesses, specifically, the investment decision, in order to better explain this phenomenon.

\section{REFERENCES}

Andalaft, S. \& Quezada, F. (2001). Analysis of the Strategic Investments, Methods and Applications. Revista Teoría, 10, 89-97.

Astrachan, J., \& Shanker, M.C. (2003). Family Businesses Contribution to The U.S. Economy: A Closer Look. Family Business Review, 16 (3), 211-219. 
Barney, J. (1991). Firm Resources and Sustained Competitive Advantage. Journal of Management, 1 (17), 99-120.

Boshoff, C. (1999). An instrument to measure satisfaction with transaction-specific service recovery. Journal of Service Marketing, 1(3), 236-249.

Brealey, R. \& Myers, S. (1991). Principles of Corporate Finance. Fourth Edition, Madrid, Spain: McGraw-Hill.

Brealey, R. \& Myers, S. (1996). Principles of Managerial Financing. Third Edition, Madrid, Spain: McGraw-Hill.

Chrisman, J., Chua, J., \& Sharma, P. (2005). Trend and Directions in Development of a Strategic Management Theory of the Family Firm. Entrepreneurship: Theory and Practice, 29, 555-575.

Chua, J., Chrisman, J., \& Sharma, P. (1999). Defining the Family Business by Behavior. Entrepreneurship: Theory and Practice, 23, 19-39.

Churchill, G. (1979). A paradigm for developing better measures of marketing constructs. Journal of Marketing Research, 26, 64-73.

Churchill, N.C., \& Hatten, K.J. (1997). Non-market Based Transfer of Wealth and Power: A Research Framework for Family Businesses. Family Business Review, 10, 53-67.

Collins, D., \& Montgomery, C. (1995). Competing on Resources: Strategy in the 1990s. Harvard Business Review, 73, 118-128.

Danielson, M., \& Scott, J. (2007). A note on Agency Conflicts and the Small Firm Investment Decision. Journal of Small Business Management, 45(1), 157-175.

Davis, J.A. (2006). Inside the Family Business DNA. Harvard Business Review, 84(8), 36-40.

Degadt, J. (2003). Business Family and Family Business: Complementary and Conflicting Values. Journal of Enterprising Culture, 11, 79-397.

Del Sol, P. (1999). Evaluation of Strategic Decisions. First Edition, Santiago, Chile: McGraw-Hill.

Del Sol, P., \& Ghemawat, P. (1999). Strategic Valuation of Investment under Competition. Interfaces, 29(6), 42-56.

Dierickx, I., \& Cool, K. (1989). Asset Stock Accumulation and Sustainability of Competitive Advantage. Management Science, 12(35), 1504-1513.

Dodero, S. (2002). The Secret of the Successful Family Businesses. Santiago, Chile: McGraw-Hill.

Ghemawat, P., \& Del Sol, P. (1998). Commitment versus Flexibility?. California Management Review, 40(4), 3-18. 
Gomez-Mejia, L., Núñez-Nickel, M., \& Gutierrez, I. (2001). The Role of Family Ties in Agency Contracts. Academy of Management Journal, 44, 81-95.

Handler, W. (1989). Methodological Issues and Considerations in Studying Family Businesses. Family Business Review, 2(3), 257-276.

Hax, A.C., \& Majluf, N.S. (1996). The Strategy Concept and Process: A Pragmatic Approach. New Jersey: Prentice Hall Inc.

Hodder, J., \& Riggs, H. (1985). Pitfalls in Evaluating Risky Projects. Harvard Business Review, 63(1), 128-135.

Kaplan, S.N., \& Ruback, R.S. (1995). The Valuation of Cash Flow Forecasts: An Empirical Analysis. The Journal of Finance, 50, 1059-1094.

Leftwich, R.H. \& Eckert, R.D. (1987). Pricing System and Allocation of Resources. Ninth Edition, New Cork: Latino-American Edition.

Llanos, O. (2005). Investments from an Strategic Perspective. In proceedings of the Latin-American Conference on Strategy, Santa Cruz de la Sierra, Bolivia.

McConnell, J.J., \& Muscarella, C.J. (1985). Corporate Capital Expenditure Decisions and Market Value of the Firm. Journal of Financial Economics, 14, 399-422

Miller, E.J., \& Rice, A.K. (1967). Systems of Organizations, in Task and Sentient Systems and Their Boundary Control. London: Tavistock Publications.

Morck, R., \& Bernard, Y. (2004). Family Control and the Recent Seeking Society. Entrepreneurship: Theory and Practice, 28, 391-409.

Nunnaly, J. (1978). Psychometric Theory (2nd ed.). New York: McGraw Hill.

Peteraf, M. A. (1993). The Cornerstones of Competitive Advantage: A ResourceBased View. Strategic Management Journal, 14, 179-191.

Peterson, R. (1995). Relationship marketing and the customer. Journal of the Academy of Marketing Science, 23, 278-281.

Porter, M.E. (1980). Competitive Strategy: Techniques for Analyzing Industries and Competitors. First Edition, New York: Free Press.

Porter, M.E. (1985). The Competitive Advantage: Creating and Sustaining Superior Performance, Primera Edición. New York: Free Press.

Porter, M.E. (1991) Towards a Dynamic Theory of Strategy. Strategic Management Journal, 12, 95-117.

Porter, M.E. (1996). What is Strategy?. Harvard Business Review, 17, 33-47.

Rialp i Criado, A. (1998). The Case Method as Investigation Tool and Its Application to the Management Studies. In proceedings of the Congress on Research Methods, La Rioja, Argentina. 
Ross, S., Westerfield, R., \& Jeffey, J. (1997). Corporate Finance. Fifth Edition, Madrid, Spain: McGraw Hill- Irwin.

Sapag, N. (2001). Project Evaluation. First Edition, Buenos Aires, Argentina: Prentice Hall.

Schulze, W., Lubatkin, M., Dino, R., \& Bucholtz, A. (2001). Agency Relationships in Family Firms: Theory and Evidence. Organization Science, 12, 99-116.

Schulze, W., Lubatkin, M., \& Dino, R. (2003). Toward a Theory of Agency and Altruism in Family Firms. Journal of Business Venturing, 18, 473-490.

Ward, J.L. (2001). Differences in the Strategy of Family-Oriented Business. Retrieved Jan. 8, 2007, from http://www.uai.cl/p4_centros/site/pags/20031009195613.html.

Ward, J. L. (2002). New Strategies: The Advantage of Family-Oriented Businesses. Retrieved Jan. 8, 2007, from http://www.uai.cl/p4_centros/site/pags/2003100919 5421.html.

Wernerfelt (1984). A resource-based view of the firm. Strategic Management Journal, 5(2), 171-180.

Woolridge, J.R. (1988). Competitive Decline: Is a Myopic Stock Market to Blame?. Journal of Applied Corporate Finance, 1, 26-36. 